\title{
PUSHOVER ANALYSIS-TO STUDY SEISMIC PERFORMANCES OF VERTICAL IRREGULAR STRUCTURE
}

\author{
D.N.Shinde ${ }^{1}$, Patil Sadhana $\mathbf{M}^{2}$ \\ ${ }^{1}$ Associate Professor, Department of Civil Engineering, P.V.P.I.T. Budhgaon, Maharashtra, India \\ ${ }^{2}$ Student, Department of Civil Engineering, P.V.P.I.T. Budhgaon, Maharashtra,
}

\begin{abstract}
Now a day, a lot of attention is given to the make structure as earthquake resistant. Due to the earthquake huge amount of damage will takes place. To prevent this damage it is necessary to design earthquake resistant structures. So that the pushover analysis is one of the method to work out the seismic behavior of the structure. Pushover analysis is nonlinear static analysis to evaluate seismic performance of the building under the lateral loads. As a point of view of architectural consequence it is not possible to plan with regular shape. The present study represents the seismic response of the vertical irregular building frame as compared to the regular building frame. There are various types of vertical irregularities. The building frame considered for this study that are irregular in elevation. The present work is concerned with the static nonlinear analysis of G+7RCC building frame with and without vertical irregularity by using design and analysis software ERABSv9.5.0 and both building frame design designed as per the Indian Standard 456:2000 and 1893:2002.The aim of present work is to check the seismic effect of vertical irregularity on building frame in terms of parameter lateral displacement, story drift and story shear, spectral acceleration and spectral displacement.
\end{abstract}

Keywords: Pushover Analysis, Vertical Irregularity, Story Drift, Story Shear, Lateral Displacement, Spectral Acceleration, Spectral Displacement.

\section{INTRODUCTION}

Earthquake occurred in multi-storied building shows that if the structures are not well designed and constructed with an adequate strength it leads to the complete collapse of the structures. To ensure safety against seismic forces of multistoried building, there is need to study of seismic analysis to design earthquake resistance structures.

The regular building have the building configuration almost same about the axis and there is lack of symmetry and discontinuity in geometry in case of irregular building. there are various types of vertical irregularities-i) stiffness irregularity ii)mass irregularity iii)vertical geometric irregularity iv)discontinuity in capacity-weak storey v) In plane discontinuity in vertical element resisting lateral force. The irregularity in elevation i.e. vertical geometric irregularity is considered for this work. Two building frame with and without vertical irregularity is considered. And the effect of vertical irregularity is studied in terms of parameter lateral displacement, story drift and story shear.A plot of the spectral displacement verses spectral acceleration i.e pushover curve is obtained by this analysis, which gives the performance point for the particular structure.

\section{CASE STUDY DETAILS:}

The RC building frame of $\mathrm{G}+7$ floors is considered for obtaining performance point. Itconsists of 6 bays along both the directions. The typical storey height and ground storey height is same i.e. $3.0 \mathrm{~m}$. The bay width is $4.5 \mathrm{~m}$ along $\mathrm{x}$ direction and $3 \mathrm{~m}$ along Y-direction. The frame is situated in zone III. The structural design data and seismic data is same for both the model.

M-I-Building frame without vertical irregularity

M-II-building frame with vertical irregularity.

\subsection{Design Data:}

Type of structure

: RC Moment Resisting Frame

Seismic zone : III

Zone factor

Number of storey

: $\mathrm{G}+7$

Floor height

$: 3 \mathrm{~m}$

Base Floor height

$: 3 \mathrm{~m}$

Infill Wall

: $230 \mathrm{~mm}$ thick

Live load 
Floor Finish

Earthquake load

$: 1.0 \mathrm{kN} / \mathrm{m}^{2}$

Type of soil

: As per IS-1893 (Part 1)200 2

: Type II, medium soil.

\subsection{Description of Building Frame:}

No. Bays along $\mathrm{X}$ axis : 6

No. Of bays along $\mathrm{Y}$ axis : 6

Spacing along $X$ axis : $4.5 \mathrm{~m}$

Spacing along $\mathrm{Y}$ axis : $3 \mathrm{~m}$

Story height: $3 \mathrm{~m}$

No. Of floors: $\mathrm{G}+7$

Sizes of column : C1 $=520 X 480 \mathrm{~mm}$ for ground floor

$\mathrm{C} 2=480 \times 420 \mathrm{~mm}$ for $1^{\text {st }}$ floor

$\mathrm{C} 3=420 \times 380 \mathrm{~mm}$ for $2^{\text {nd }}$ floor

$\mathrm{C} 4=380 \times 340 \mathrm{~mm}$ for $3^{\text {rd }}$ floor

C $5=340 \times 300 \mathrm{~mm}$ for $4^{\text {th }}$ floor

$\mathrm{C} 6=300 \times 250 \mathrm{~mm}$ for $5^{\text {th }}$ floor

$\mathrm{C} 7=280 \times 220 \mathrm{~mm}$ for $6^{\text {th }}$ floor

$\mathrm{C} 8=240 \times 200 \mathrm{mmfor} 7^{\text {th }}$ floorsizes of column :

$\mathrm{B} 1=420 \times 380 \mathrm{~mm}$ for $1^{\text {st }}$ floor

$\mathrm{B} 2=420 \times 380 \mathrm{~mm}$ for $2^{\text {nd }}$ floor

$\mathrm{B} 3=380 \times 340 \mathrm{~mm}$ for $3^{\text {rd }}$ floor

B4 $=380 \times 340 \mathrm{~mm}$ for $4^{\text {th }}$ floor

B5 $=340 \times 320 \mathrm{~mm}$ for $5^{\text {th }}$ floor

B6 $=340 \times 320 \mathrm{~mm}$ for $6^{\text {th }}$ floor

$\mathrm{B} 7=320 \times 300 \mathrm{~mm}$ for $7^{\text {th }}$ floor

$\mathrm{B} 8=300 \times 260 \mathrm{~mm}$ for $8^{\text {th }}$ floor

\section{MODELING AND ANALYSIS OF BUILDING}

\section{FRAME WITHOUT VERTICAL IRREGULARITY}

\section{(M-I)}

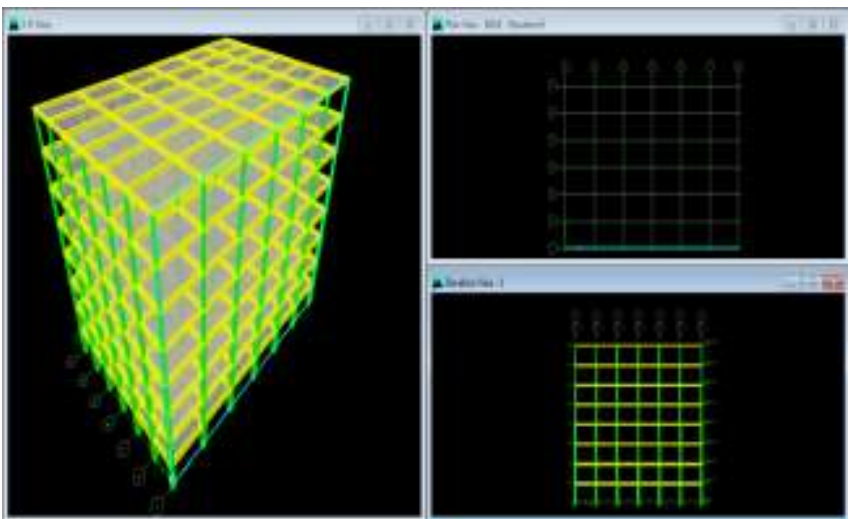

Fig.3.1.Plan, elevation \& 3D view (M-I)

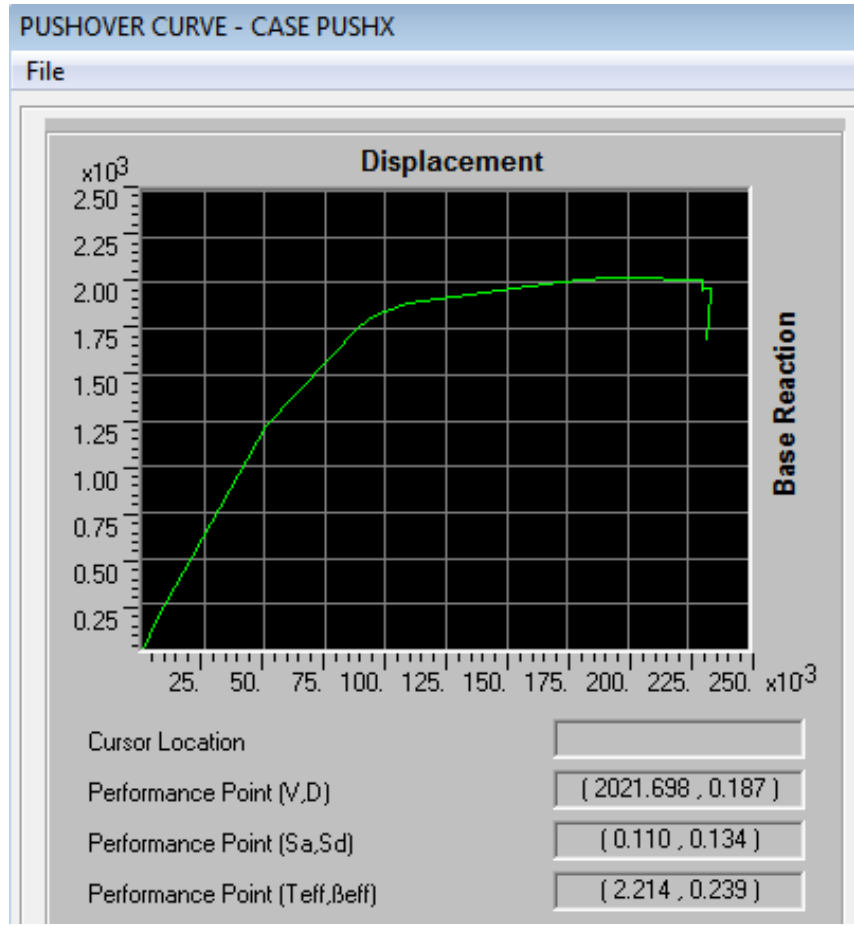

Fig.3.2.pushover curve (M-I)

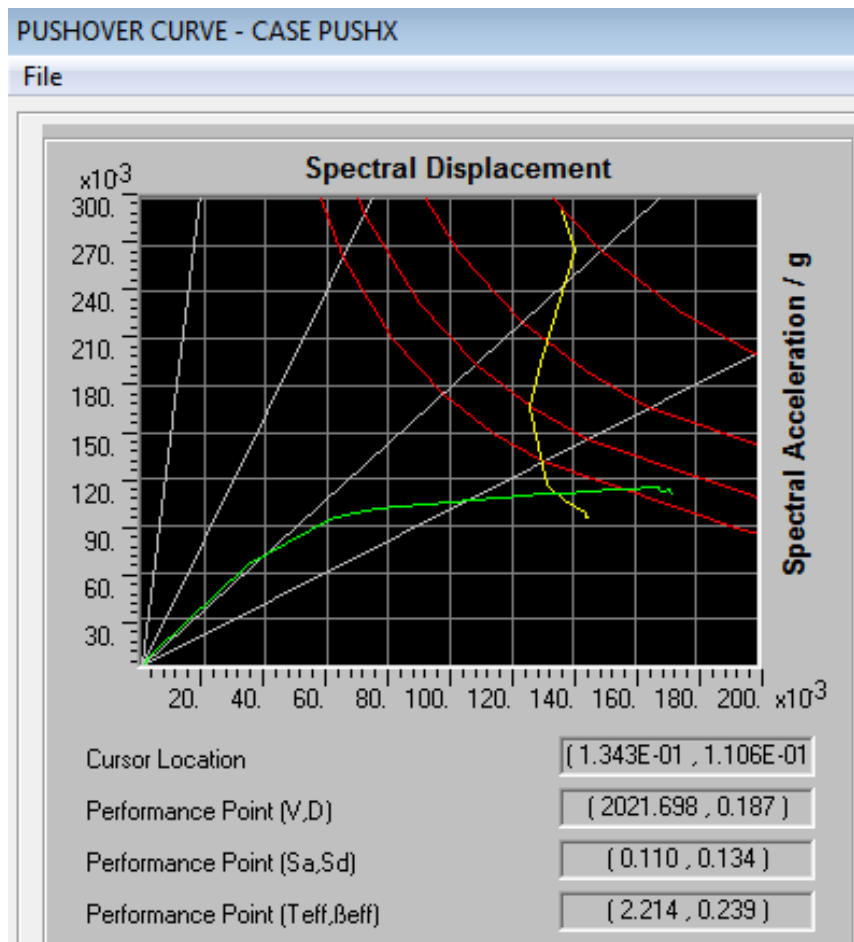

Fig.3.3 Performance point-Capacity and demand curve (M-

I)

The demand curve and capacity curves are obtained to get the performance point of the structure. The performance point is obtained as per ATC40 capacity spectrum method. For building frame without vertical irregularity (M-I) base shear at the performance point is $2021.698 \mathrm{kN}$. 


\section{MODELING AND ANALYSIS OF BUILDING}

FRAME WITH VERTICAL IRREGULARITY

\section{(M-II)}

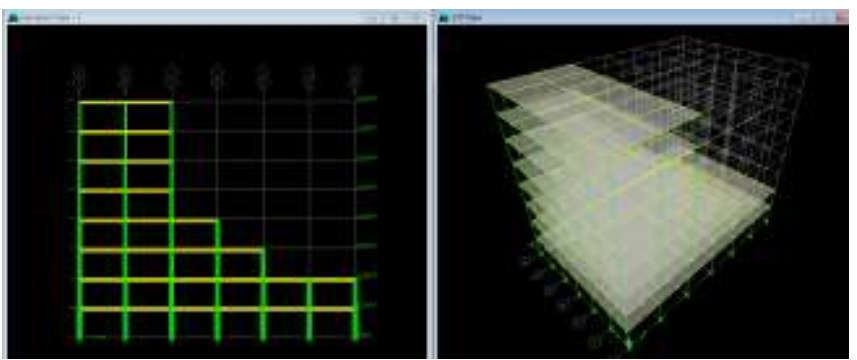

Fig.4.1. elevation \& 3D view (M-II)

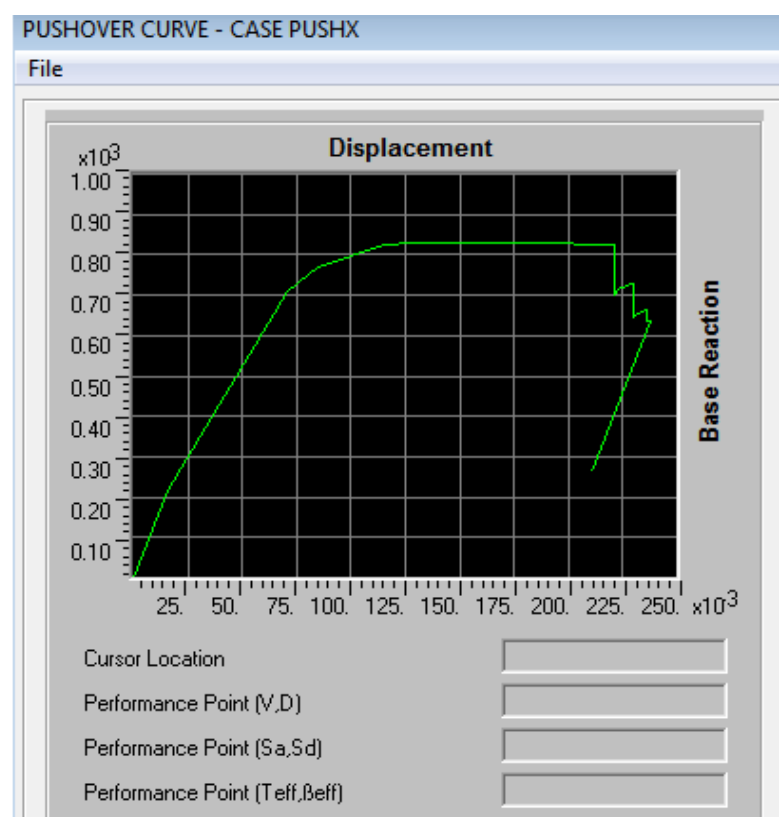

Fig.4.2.pushover curve (M-II)

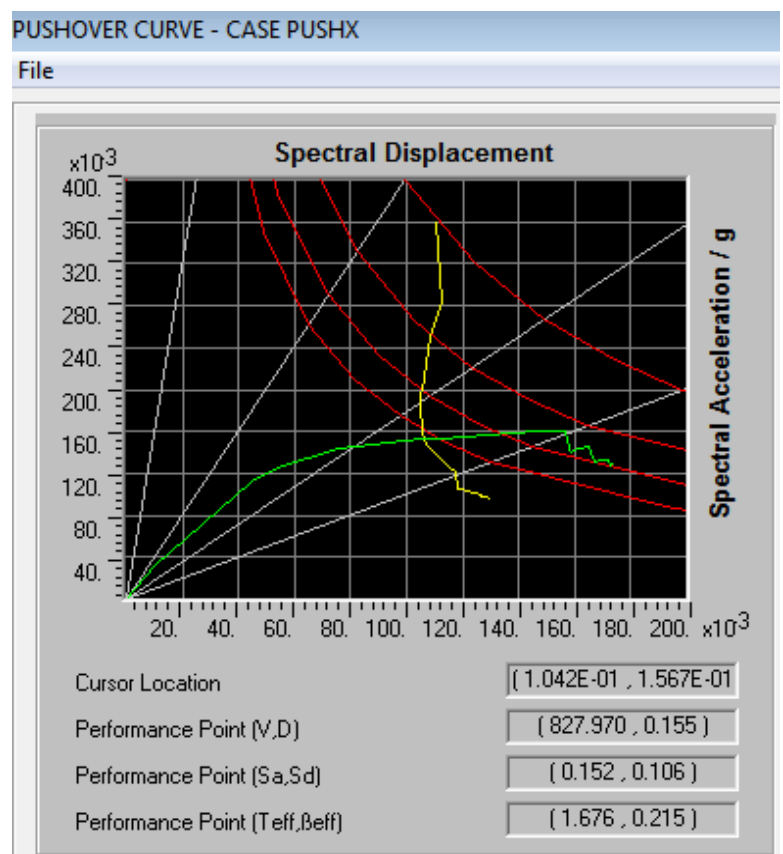

Fig.4.3 Performance point-Capacity and demand curve (M-II)
For the building frame with vertical irregularity (M-II) base shear at the performance point is $827.970 \mathrm{kN}$.

\section{PUSHOVER ANALYSIS}

\subsection{Lateral Displacement}

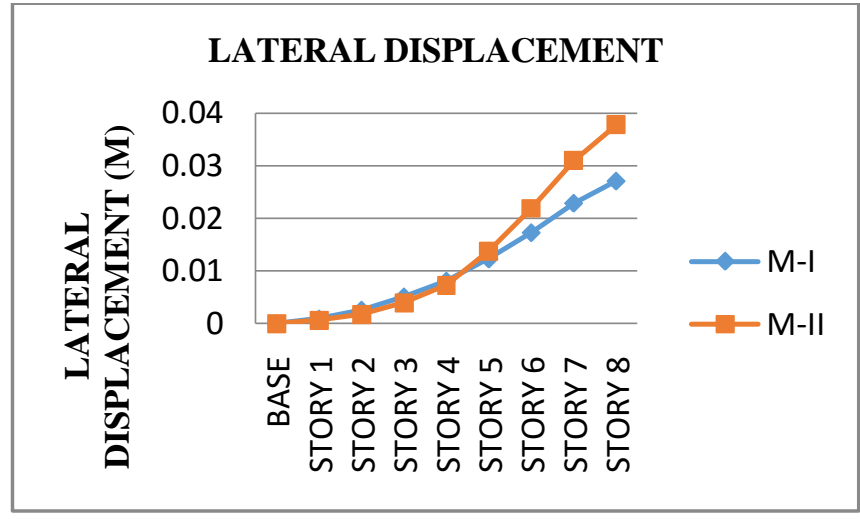

Fig.5.1..Variation in lateral displacement

\subsection{Story Drift}

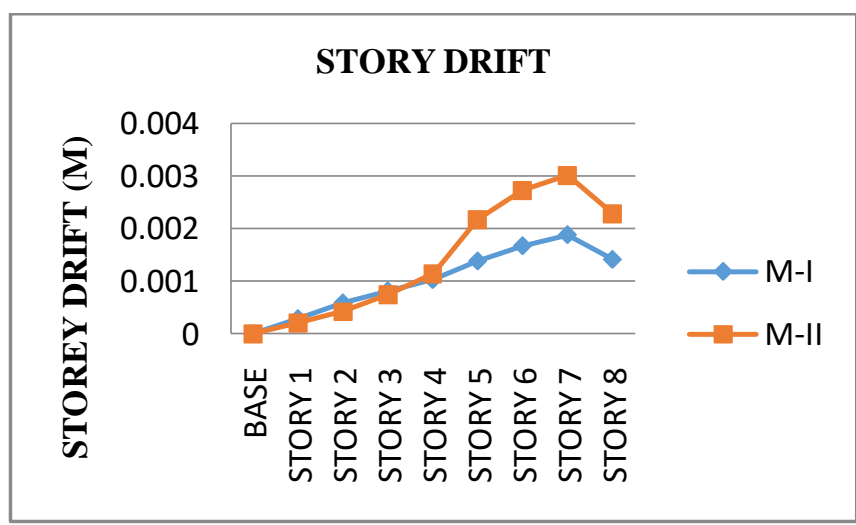

Fig.5.2. variation in story drift

\subsection{Story Shear}

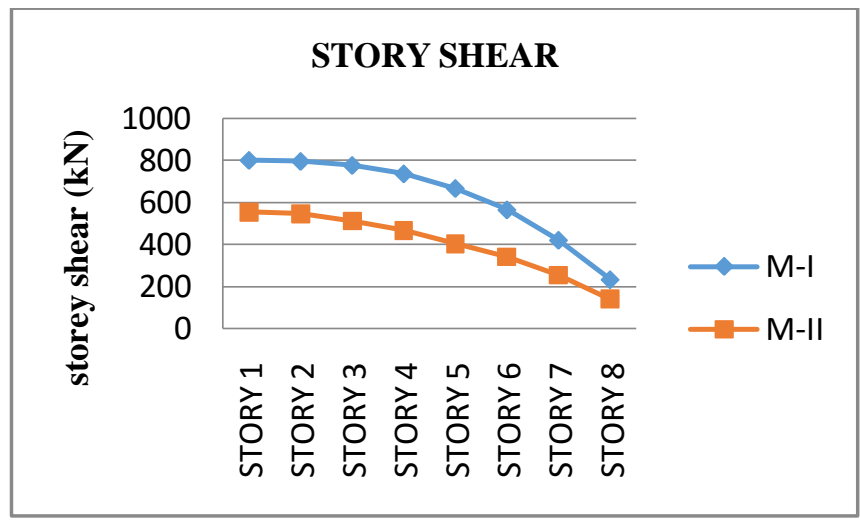

Fig.5.3.variation in story shear 


\subsection{Analysis Result}

Table- comparison of building performance $(\mathrm{X})$

\begin{tabular}{|l|l|l|}
\hline & M-I & M-II \\
\hline $\begin{array}{l}\text { Base shear at performance } \\
\text { point }(\mathrm{kN})\end{array}$ & 2021.698 & 827.97 \\
\hline $\begin{array}{l}\text { Displacement at performance } \\
\text { point }(\mathrm{kN})\end{array}$ & 0.187 & 0.115 \\
\hline Spectral acceleration (m/s2) & 0.11 & 0.152 \\
\hline Spectral Displacement (m) & 0.134 & 0.106 \\
\hline Story displacement (m) & 0.0271 & 0.0378 \\
\hline Story Drift (m) & 0.001878 & 0.003011 \\
\hline
\end{tabular}

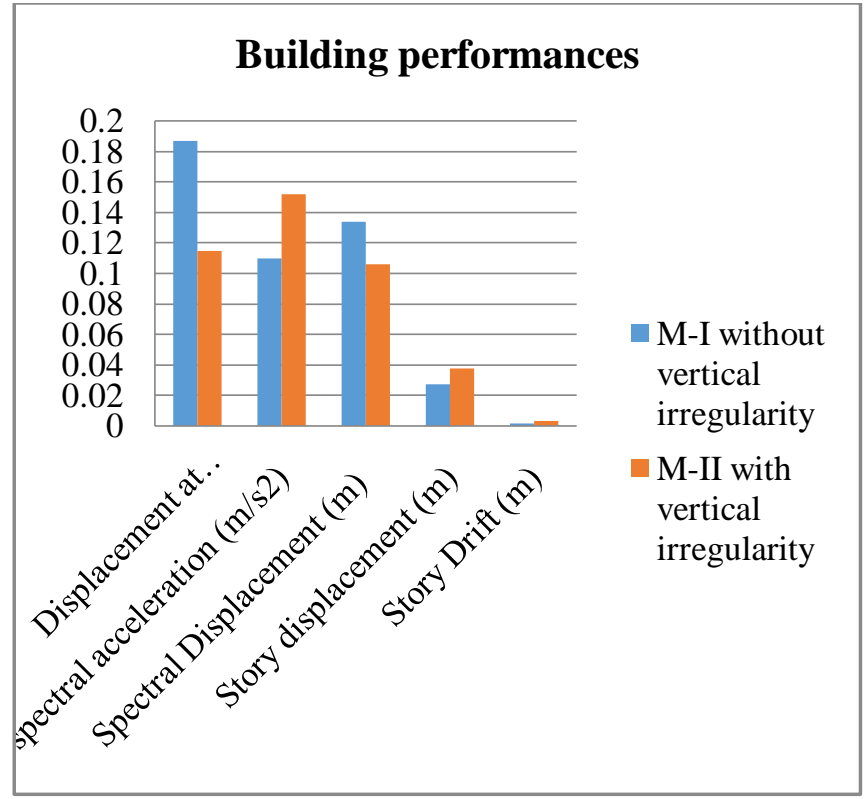

Fig.5.4. 1.building performances

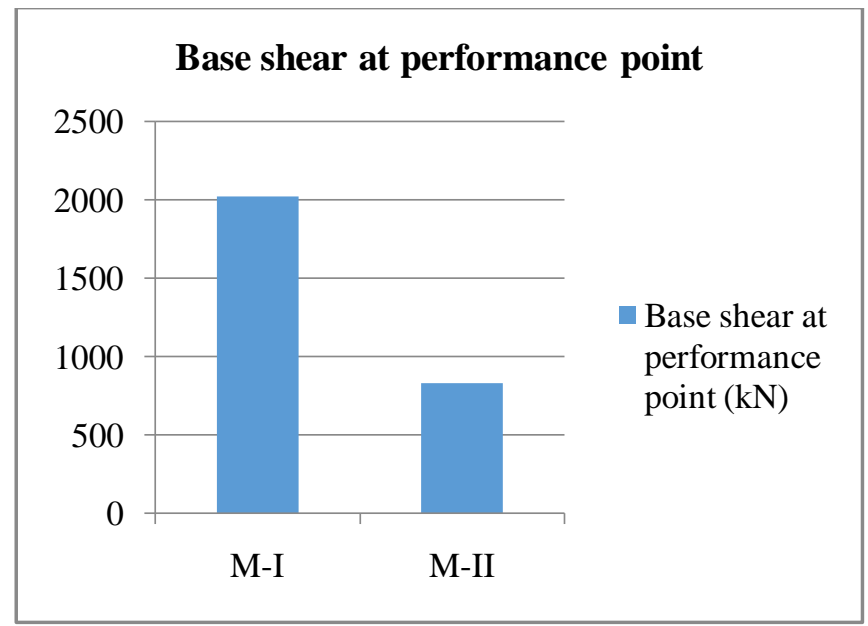

Fig.5.4.2.building performances-variation in base shear

From the above result it is observed that overall performance of irregular structure is critical as compared to the regular structure.

\section{CONCLUSION:}

G+7 building frame model (M-I) without vertical irregularity and (M-II) with verticalirregularuty is analyzed by using design and analysis software ETABSv9.5.0. The present study has lead to the following conclusions:

1) The lateral displacement and storey drift of vertical irregular structure is more as compared to the vertical regular structure.(Fig.5.4.1)

2) By the provision of vertical irregularity the spectral acceleration get increases and spectral displacement get reduces.(fig.5.4.1)

3) The building frame with vertical irregularity having less performance point value as compared to the building frame without vertical irregularity. It means the lateral load capacity of regular structure is more as compared to the irregular structure.

\section{REFERENCES:}

[1]. Chatpan Chintanapakdee1, and Aanil k. Chopra(2004) "Evaluation of modal Pushover Analysis Using Vertically Irregular Frames" 13th world conference on earthquake engineering vancouver, B.C. Canada.

[2]. Jonathan Chambers and Trevor Kelly(2004) "Nonlinear Dynamic Analysis - The Only Option For Irregular Structures",13th world conference on Earthquake Engineering. vancouver, B.C. Canada

[3]. Alessandro Galasco, Sergio Lagomarsino And Andrea Penna (2006) "The Use of Pushover Analysis For Existing Masonry Buildings" First European Conference on Earthquake Engineering and Seismology ,Geneva, Switzerland.

[4]. T.L. Karavasilisa, N. Bazeosa, D.E. Beskos(2007) "Seismic response of plane steel MRF with setbacks: Estimation of inelastic deformation demands".

[5]. N. fallah, S. PourzeYnali and M.I. Hafezi (2011) "Accuracy evaluation of the modal pushover analysis method in the prediction of seismic response of vertically irregular frames" ,IJST, Transactions of Civil Engineering.

[6]. T. Mahdi V. SoltanGharaie (2011) " Evaluation of the accuracy of quasi-static pushover analysis method" Proceedings of the Ninth Pacific Conference on Earthquake Engineering Building an EarthquakeResilient Society.

[7]. KonuralpGirgin and KutluDarılmaz.(December 2007 )“ Seismic Response of Infilled Framed Buildings Using Pushover Analysis". Department of Civil Engineering, Istanbul Technical University, 34469, Maslak, Istanbul, Turkey Volume 54, Number 5. 5 December 2007

[8]. IS:456:2000 Plain and Reinforced code of practice, IS: 875 Code of practice for design loads, IS:1893(Part1):2002 Criteria for earth quake resistant design of structure, IS:13920:1993 Ductile detailing of RCC structure subjected to earth quake force.

[9]. Murthy C.V.R, Learning earthquake design

[10]. Agrawal, ShrikhandeMansih, earth quake resistant design of structures

[11].Chopra A.K., Dynamics of structures- theory and applications to earthquake engineering 